\title{
Organic substrate quality as the link between bacterioplankton carbon demand and growth efficiency in a temperate salt-marsh estuary
}

\author{
Jude K Apple ${ }^{1}$ and PA del Giorgio ${ }^{2}$ \\ ${ }^{1}$ Horn Point Laboratory, University of Maryland Center for Environmental Science, Cambridge, MD, USA and \\ ${ }^{2}$ Département des sciences biologiques, Université du Québec à Montréal, Montréal, Canada
}

\begin{abstract}
Bacterioplankton communities play a key role in aquatic carbon cycling, specifically with respect to the magnitude of organic carbon processed and partitioning of this carbon into biomass and respiratory losses. Studies of bacterioplankton carbon demand (BCD) and growth efficiency (BGE) frequently report higher values in more productive systems, suggesting these aspects of carbon metabolism may be positively coupled. However, the existence of such a relationship in natural aquatic systems has yet to be identified. Using a comprehensive 2-year study of bacterioplankton carbon metabolism in a temperate estuary, we investigated BCD and BGE and explored factors that may modulate their magnitude and coherence, including nutrient concentrations, dissolved nutrient uptake and source and quality of dissolved organic carbon (DOC). During the course of our study, $B C D$ ranged from 0.4 to $15.9 \mu \mathrm{g} \mathrm{I}^{-1} \mathrm{~h}^{-1}$, with an overall mean of $3.8 \mu \mathrm{g} \mathrm{I}^{-1} \mathrm{~h}^{-1}$. Mean BGE was similar to that reported for other estuarine systems $(0.32)$ and of comparable range (that is, $0.06-0.68$ ). Initial analyses identified a negative correlation between BCD and BGE, yet removal of the effect of temperature revealed an underlying positive coupling that was also correlated with long-term DOC lability. Whereas BCD was weakly related to ambient DOC concentrations, neither BCD nor BGE showed any relationship with ambient nutrient concentrations or nutrient uptake stoichiometries. We conclude that in this carbon-rich estuary, organic matter source and quality play an important role in regulating the magnitude of carbon metabolism and may be more important than nutrient availability alone in the regulation of BGE.
\end{abstract}

The ISME Journal (2007) 1, 729-742; doi:10.1038/ismej.2007.86; published online 18 October 2007

Subject Category: geomicrobiology and microbial contributions to geochemical cycles

Keywords: bacterioplankton; DOC; estuary; growth efficiency; lability

\section{Introduction}

Bacterioplankton carbon demand (BCD) and growth efficiency (BGE) describe two fundamental aspects of carbon cycling in aquatic systems-the magnitude of organic carbon consumed by bacterioplankton communities and the extent to which this organic matter is partitioned into biomass and respiratory losses. The majority of studies investigating bacterioplankton carbon metabolism in natural waters have focused on measurements of

Correspondence: J Apple, Marine Biogeochemistry, US Naval Research Laboratory, 4555 Overlook Avenue Southwest, Washington, DC 20375, USA.

E-mail: jude.apple@nrl.navy.mil

Received 28 February 2007; revised 3 September 2007; accepted 5 September 2007; published online 18 October 2007 growth and production, providing valuable information regarding the regulation of these communities by environmental factors (Coveney and Wetzel, 1992; Felip et al., 1996), their role in carbon and nutrient cycling (Ducklow et al., 1986; Sherr et al., 1988; Hoch and Kirchman, 1995) and their response to system-level nutrient enrichment (Revilla et al., 2000; Apple et al., 2004). However, the range and variability of BGE in natural waters (del Giorgio and Cole, 1998) indicates that bacterial production (BP) and respiration (BR) are not always tightly coupled. This leaves in question the extent to which welldescribed patterns in bacterioplankton growth and production reflect those of bacterioplankton respiration, carbon demand and growth efficiency.

Bacterial growth, BP and BR are typically higher in more productive or nutrient-rich systems (Bjørnsen et al., 1989; Pace and Cole, 2000; Paerl et al., 2003; 
Apple et al., 2004). This would suggest that over broad environmental gradients (that is, oligotrophic open oceans to productive coastal and estuarine systems), BCD must also tend to increase, as observed patterns in BP and bacterial growth (Cole et al., 1988) cannot be driven by changes in BGE alone. Similarly, comparative studies have shown that BGE tends to increase along these same gradients (del Giorgio and Cole, 1998). Thus, the existing information would suggest that over broad gradients of ecosystem productivity, BCD and BGE would tend to covary positively, such that systems with high BCD would also tend to have relatively high BGE. However, it has yet to be determined if this pattern actually exists in natural systems and if so, what the basis is for this covariation. Such a pattern could result from a strong physiological link between BCD and BGE, or alternatively each of these two measures of carbon metabolism could be regulated by different environmental factors that in turn covary with some aspect of system productivity. Establishing the nature of these links is critical to our understanding of the regulation of bacterial carbon metabolism in aquatic ecosystems.

Our study investigates the coherence of BCD and BGE along environmental gradients within a temperate estuarine ecosystem and explores environmental factors shaping this relationship. We hypothesize that BCD and BGE are positively correlated and examine the influence of the lability dissolved organic carbon (DOC) and dissolved nutrient uptake on this relationship. Our results suggest that carbon demand and growth efficiency are indeed positively coupled, once the effect of temperature is removed, and that inorganic nutrients do not seem to play a major role in regulating either of these processes or their coherence. We conclude that variations in the lability of the DOC pool and in the quality organic substrates have a strong influence on the consumption of carbon by bacterioplankton and its partitioning between BR and BP.

\section{Materials and methods}

\section{Sample collection}

Our study was conducted in the Monie Bay component of Maryland's National Estuarine Research Reserve System, a temperate salt-marsh system located on the eastern shore of Chesapeake Bay $\left(38^{\circ} 13.50^{\prime} \mathrm{N}, 75^{\circ} 50.00^{\prime} \mathrm{W}\right)$ and consisting of an open bay and three tidally influenced creeks varying in size, agricultural land use, dissolved nutrient concentrations and source and concentration of DOC. Monie Creek (MC) and Little Monie Creek (LMC) are the largest of the three creeks and characterized by steep gradients in dissolved nutrient concentrations attributed to agricultural land use, while Little Creek (LC) is a relatively pristine system with an undeveloped watershed consisting primarily of marsh and forest (Apple et al., 2004).
The source and concentration of DOC also differs dramatically among these creek systems, with higher concentrations of terrestrial DOC recorded in MC (Apple et al., 2004). Each of these creeks feed into and interacts tidally with the relatively shallow $(<2 \mathrm{~m})$ and moderately sized $\left(\sim 5 \mathrm{~km}^{2}\right)$ Monie Bay (hereafter Open Bay, OB), which is a tributary of Tangier Sound and ultimately Chesapeake Bay. Details regarding sample collection, laboratory analyses and the utility of this system for investigating the relationship between environmental parameters and bacterioplankton community metabolism are mentioned in other studies by our group (Apple et al., 2004, 2006).

Each of 10 stations within the OB system was visited monthly between March 2000 and January 2002, with biweekly sampling during summer months (June-August). More extensive transects encompassing four additional upstream sites in MC and LMC were conducted periodically throughout the sampling period. Stations were accessed via a small boat and water-column physiochemical properties were recorded. Approximately $20 \mathrm{l}$ of near-surface $(<0.5 \mathrm{~m})$ water was collected from each site immediately following high tide and transported in HDPE Nalgene carboys back to the laboratory for filtration and subsampling for BP, respiration, growth efficiency, dissolved nutrient concentrations and the concentration and optical characteristics of DOC. Elapsed time from sampling to filtration rarely exceeded $2 \mathrm{~h}$.

\section{Water column analyses}

Approximately $1 \mathrm{l}$ of GF/F-filtered sample water from each station was used to determine DOC and dissolved nutrient concentrations. Subsamples for DOC were acidified with $100 \mu \mathrm{l}$ of $1 \mathrm{~N}$ phosphoric acid and held at $4{ }^{\circ} \mathrm{C}$ until analysis. DOC content was determined with a Shimadzu high-temperature catalyst carbon analyzer (Sharp et al., 1995). Nutrient samples were stored at $-25^{\circ} \mathrm{C}$ until analyzed for phosphate (that is, $\mathrm{PO}_{4}^{3-}$, soluble reactive phosphorus), nitrite and nitrate $\left(\mathrm{NO}_{x}\right)$, total dissolved nitrogen (TDN), total dissolved phosphorus (TDP) and ammonium $\left(\mathrm{NH}_{4}^{+}\right)$following standard methods (Strickland and Parsons, 1972; Valderrama, 1981; Whitledge et al., 1981). Photospectral absorbance of colored dissolved organic matter (CDOM) was determined on GF/F-filtered samples by performing absorbance scans (290$700 \mathrm{~nm}$ ) using a Hitachi U-3110 spectrophotometer and either 1 or $5 \mathrm{~cm}$ quartz cuvettes, depending upon the relative concentration of CDOM. Absorptivity at $350 \mathrm{~nm}\left(a_{350}\right)$ was used as an index of CDOM concentrations (Moran et al., 2000). Specific absorbance $\left(a_{350}{ }^{*}\right)$ was determined by dividing $a_{350}$ by ambient DOC concentrations (Moran et al., 2000; Hu et al., 2002). Chlorophyll a was determined with standard methods using a Turner 10-AU fluorometer (Strickland and Parsons, 1972). 
Bacterioplankton carbon metabolism and nutrient uptake

Upon return to the lab, a small unfiltered subsample was removed from each carboy for determining total BP. Estimates of filtered BP and BR were determined by gently passing several liters of sample water through an AP15 Millipore filter $(\sim 1 \mu \mathrm{m})$ using a peristaltic pump and incubating in the dark at in situ field temperature. Water samples were contained in a flow-through incubation assembly consisting of two $4 \mathrm{l}$ Erlenmyer flasks and subsampled at 0,3 and $6 \mathrm{~h}$ (del Giorgio and Bouvier, 2002). In addition, changes in dissolved nutrient concentrations for all analytes were measured in a subset of these incubations $(n=93)$ by calculating the difference in dissolved nutrient concentrations between 0 and $18 \mathrm{~h}$ and reported in $\mu \mathrm{M}$ per hour. Uptake (or production) rates were used to calculate uptake stoichiometry and the relative contribution of nitrogen and phosphorus derived from inorganic and organic sources.

Bacterial production for whole-water and filtered samples was estimated using incorporation of ${ }^{3} \mathrm{H}$ leucine following modifications the centrifugation method of Smith and Azam (1992). A carbon conversion factor (CCF) of $3.1 \mathrm{~kg} \mathrm{C}$ mol per leucine (Kirchman, 1993) was used for all samples, as empirical estimates of CCFs among the creeks and OB were similar and did not exhibit any bias among subsystems (data not shown). Leucine uptake was measured in triplicate on each unfiltered water sample to estimate total bacterioplankton community production. Triplicate measurements of leucine uptake were also performed on the filtered fraction during incubations at each of the 0,3 and $6 \mathrm{~h}$ time points. These individual measurements were averaged to obtain a mean rate of bacterial leucine uptake for the incubation period (del Giorgio and Bouvier, 2002). Estimates of BP based on changes in particulate organic carbon (POC) during $16 \mathrm{~h}$ incubations were also determined on a subset of incubations from $\mathrm{OB}(n=8)$ and samples collected at 22 additional sites in other marsh-dominated estuaries using a Control Equipment CHN analyzer.

Bacterial respiration was determined by measuring the decline of oxygen concentration over the course of the $6 \mathrm{~h}$ incubation, with longer incubations $(8 \mathrm{~h})$ used at lower ambient water temperatures $\left(<15^{\circ} \mathrm{C}\right)$. Dissolved oxygen concentrations were measured using membrane-inlet mass spectrometry (Kana et al., 1994). A respiratory quotient of 1.0 was used to convert oxygen measurements to carbon values. Rates of BP and BR were reported as $\mu \mathrm{g} \mathrm{l}^{-1} \mathrm{~h}^{-1}$. BCD was calculated by adding simultaneous measurements of filtered $\mathrm{BP}$ and $\mathrm{BR}$, and BGE was calculated as the ratio of filtered $\mathrm{BP}$ and $\mathrm{BCD}$ $(\mathrm{BGE}=\mathrm{BP} /(\mathrm{BP}+\mathrm{BR}))$.

\section{DOC lability}

Lability of DOC in each system was characterized using a subset of the samples $(n=14)$. Approximately 11 of sample water was passed through $0.2 \mu \mathrm{m}$ Sterivex filters into duplicate $500 \mathrm{ml}$ borosilicate glass flasks. Each was inoculated with $10 \mathrm{ml}$ of AP15filtered sample water and incubated in the dark at room temperature for 24 days. DOC concentrations were measured in each flask every few days and consumption of DOC was determined using the slope of DOC concentrations vs time (that is, $\mu \mathrm{g} \mathrm{C}$ per liter per day). Percent labile DOC was determined by comparing the DOC consumed to the total DOC pool (that is, DOC consumed/initial (DOC)).

\section{Results}

Bacterioplankton carbon metabolism

Bacterial respiration and production varied greatly, ranging from 0.1 to 13.5 and 0.1 to $5.8 \mu \mathrm{g} \mathrm{C}$ per liter per hour, respectively (Table 1 ), with a relatively weak but significant positive relationship between log-transformed values (Figure $1 ; r^{2}=0.17, n=138$, $P<0.0001)$. The 2-year mean for $\mathrm{BR}(3.7 \pm 0.2 \mu \mathrm{g} \mathrm{C}$ per liter per hour, $n=139$ ) was higher than that of both total and filtered BP (Table 1). Mean total BP $(1.8 \pm 0.1 \mu \mathrm{g} C$ per liter per hour, $n=138)$ was always higher than that of the filtered fraction $(1.0 \pm 0.1 \mu \mathrm{g} \mathrm{C}$ per liter per hour, $n=139$ ), although the range of these two measures of production was similar (0.2-6.8 vs $0.1-5.8 \mu \mathrm{g} C$ per liter per hour). On average, BP attributed to the filtered fraction accounted for $63 \%$ of total BP and ranged from 47 to $90 \%$. The 2-year mean for bacterial carbon demand (BCD) was $3.75 \pm 0.2 \mu \mathrm{g}{ }^{-1} \mathrm{~h}^{-1}(n=139)$ and ranged from 0.4 to $15.9 \mu \mathrm{g} \mathrm{l}^{-1} \mathrm{~h}^{-1}$, while the overall mean BGE for the entire system was $0.32 \pm 0.02(n=139)$ and ranged from 0.06 to 0.68 .

Table 1 Two-year means for measures of bacterioplankton carbon metabolism

\begin{tabular}{|c|c|c|c|c|}
\hline Parameter & Mean \pm s.e. & Minimum & Maximum & $\mathrm{n}$ \\
\hline Bacterial respiration & $2.71 \pm 0.18$ & 0.13 & 13.5 & 139 \\
\hline Bacterial carbon demand & $3.75 \pm 0.2$ & 0.4 & 15.9 & 139 \\
\hline Bacterial growth efficiency & $0.32+0.02$ & 0.06 & 68 & 139 \\
\hline Bacterial production & $1.79+0.11$ & 0.23 & 6.8 & 138 \\
\hline Bacterial production (filtered fraction) & $1.04 \pm 0.07$ & 0.11 & 5.8 & 139 \\
\hline
\end{tabular}

Rates are reported in $\mu \mathrm{g} \mathrm{C}$ per liter per hour. 


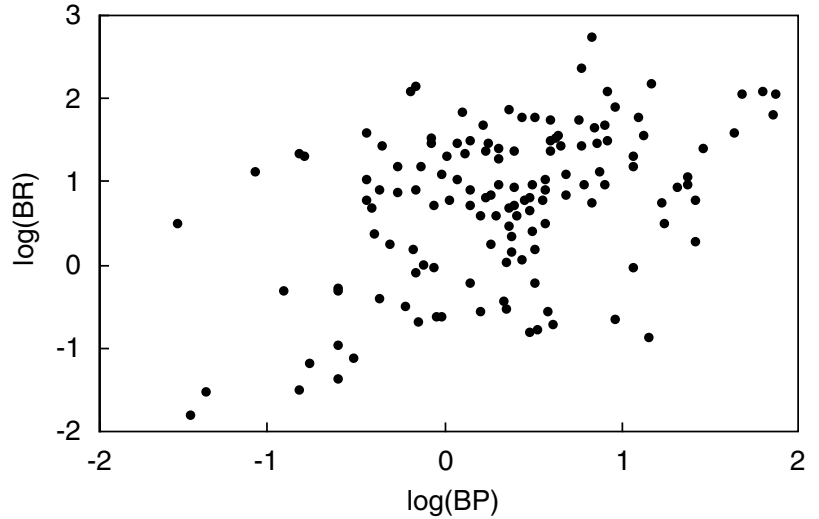

Figure 1 Paired measures of bacterial production (BP) and bacterial respiration (BR) from the entire data set $(n=138)$. Rates of carbon metabolism are reported as $\mu \mathrm{g} \mathrm{C}$ per liter per hour and log transformed.

Carbon metabolism among subsystems. Values for all measures of bacterioplankton carbon metabolism were consistently higher in LMC and lowest in OB waters, with intermediate values measured in MC and LC (Table 2). This rank order among subsystem was observed for 2-year means as well as at each individual sampling event. Bacterial carbon demand and both filtered and total BP were significantly higher in LMC than the other three subsystems. As observed with BCD, there was a distinct pattern in BGE among the subsystems, with highest BGE recorded in LMC and lowest in OB. Two-year mean BGE in each of the three tidal creeks was significantly higher than that of OB (Tukey-Kramer honestly significant difference (HSD), $P=0.09$ ) and highest in LMC and LC.

We also observed differences in lability among the four subsystems, as evidenced by consumption of DOC in long-term incubations (Figure 2). Decreases in DOC during incubations were highly significant $(P<0.0001)$, similar between replicates and relatively strong (Table 3). Both lability and percent labile were highest in LMC, while percent labile DOC in MC was lower than all other systems despite this system having the highest concentrations of DOC. Mean lability was lowest in $\mathrm{OB}$ and intermediate and statistically similar in LC and MC.

Bacterioplankton carbon demand was correlated with ambient DOC concentrations (Figure 3), with a significant yet weak relationship when the entire data set was considered $\left(r^{2}=0.07, P<0.003\right.$, $n=133$ ). Removal of data collected in MC during April 2000 and 2001 (open circles, $n=8$ ) when CDOM and inputs of terrestrial organic matter are highest in this system (Apple et al., 2004) greatly improved the relationship $\left(r^{2}=0.31, P<0.0001\right.$, $n=125)$.

Seasonal patterns in carbon metabolism. Bacterial carbon demand was highest in summer $(5.1 \pm 0.3$, $n=61$, June-August) and fall $(4.1 \pm 0.4, n=31$, September-November) and lowest in winter

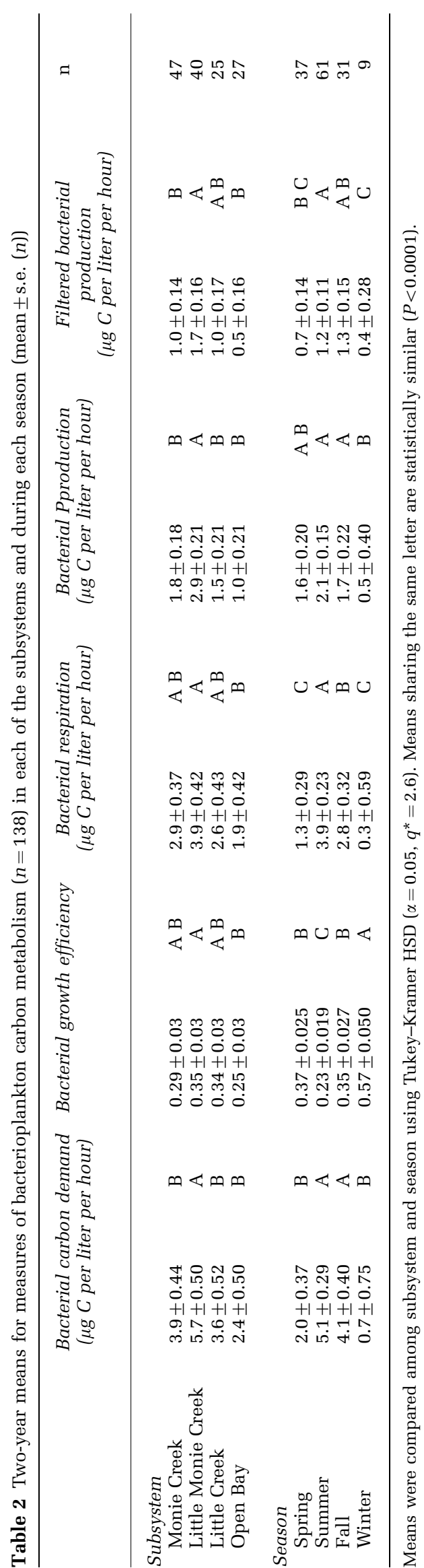

The ISME Journal 

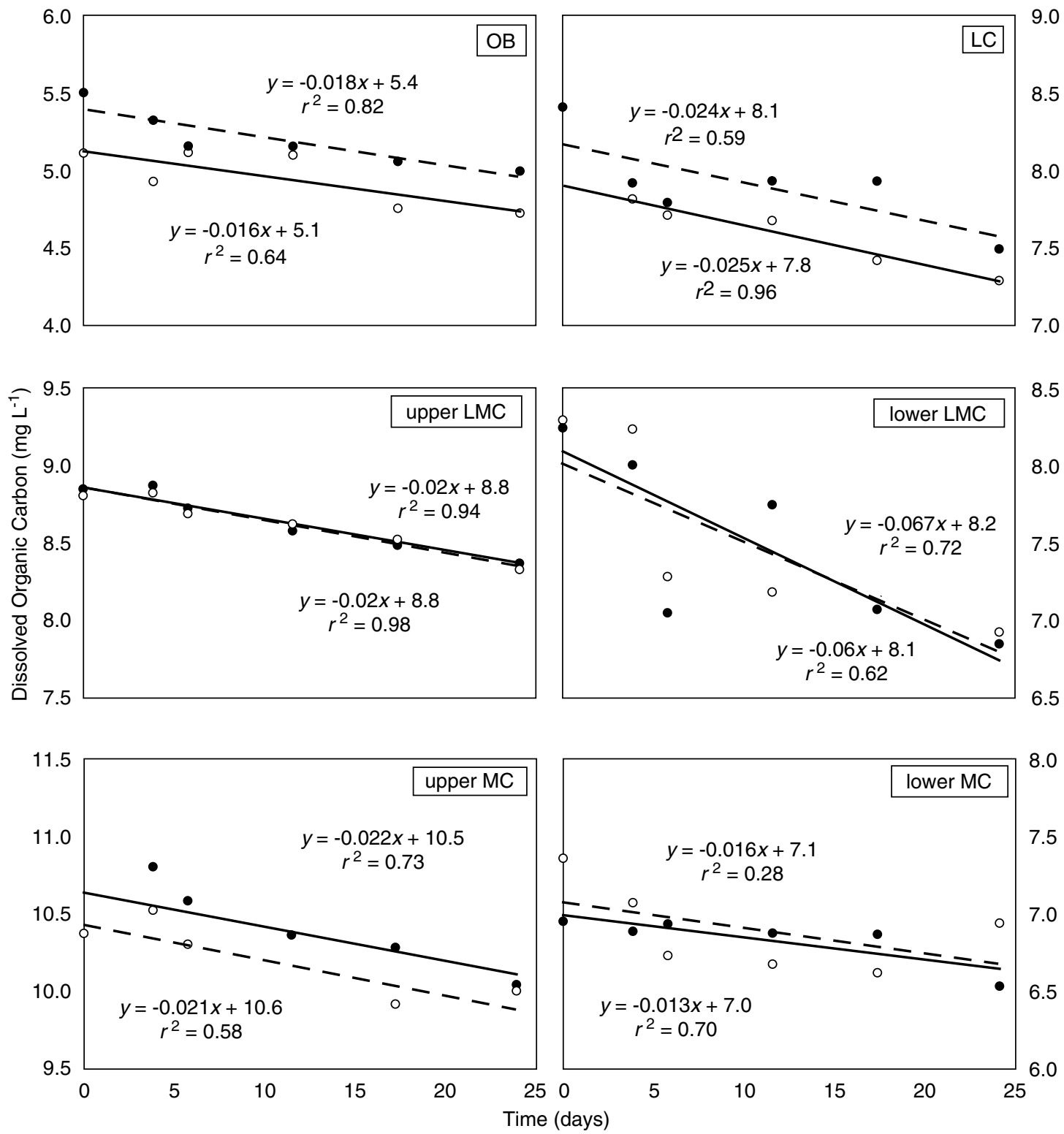

Figure 2 Consumption of DOC in 24-day incubations representing the different subsystems. Estimates of DOM lability (mg C per liter per day) were derived from the slopes of each regression. Duplicate incubations are represented by open vs closed circles.

Table 3 Characteristics of dissolved organic matter among the subsystems of Monie Bay (mean \pm s.e. $(n)$ )

\begin{tabular}{lcccc}
\hline Parameter & Monie Creek & Little Monie Creek & Little Creek & Open Bay \\
\hline Dissolved organic carbon & $12.5 \pm 0.4(51)$ & $9.6 \pm 0.5(40)$ & $7.7 \pm 0.5(36)$ & $6.0 \pm 0.5(39)$ \\
Absorbance $\left(a_{350}\right)$ & $0.23 \pm 0.01(46)$ & $0.16 \pm 0.02(38)$ & $0.11 \pm 0.02(21)$ & $0.07 \pm 0.02(24)$ \\
Specific absorbance $\left(a_{350}{ }^{*}\right)$ & $0.02 \pm 0.001(43)$ & $0.017 \pm 0.001(35)$ & $0.015 \pm 0.001(19)$ & $0.012 \pm 0.001(22)$ \\
Lability $(\mu \mathrm{g}$ C per liter per day) & $23.9 \pm 1.2(6)$ & $31.9 \pm 4.9(4)$ & $24.4 \pm 0.5(2)$ & $16.6 \pm 1.7(2)$ \\
Lability $(\%$ total DOC) & $4.4 \pm 1.8(6)$ & $14.3 \pm 6.9(4)$ & $7.3 \pm 0.5(2)$ & $8.1 \pm 0.6(2)$ \\
C:N & $23.9 \pm 1.3(62)$ & $20.3 \pm 1.4(55)$ & $26.7 \pm 1.7(36)$ & $19.6 \pm 1.7(37)$ \\
N:P & $82 \pm 11(59)$ & $84 \pm 12(55)$ & $170 \pm 15(34)$ & $129 \pm 15(35)$ \\
Chlorophyll a $\left(\mu \mathrm{gl}^{-1}\right)$ & $10.2 \pm 0.9(44)$ & $11.9 \pm 1.4(38)$ & $7.4 \pm 0.7(23)$ & $15.7 \pm 1.7(25)$ \\
\hline
\end{tabular}

Abbreviation: DOM, dissolved organic matter.

$(0.7 \pm 0.8, \quad n=9$, December-February) and spring $(2.0 \pm 0.4, n=38$, March-May; Table 2), with highly significant differences between these two seasonal groupings. A different pattern was observed for BGE, with the lowest mean efficiencies recorded for summer months $(0.23 \pm 0.02, n=61)$, highest in 


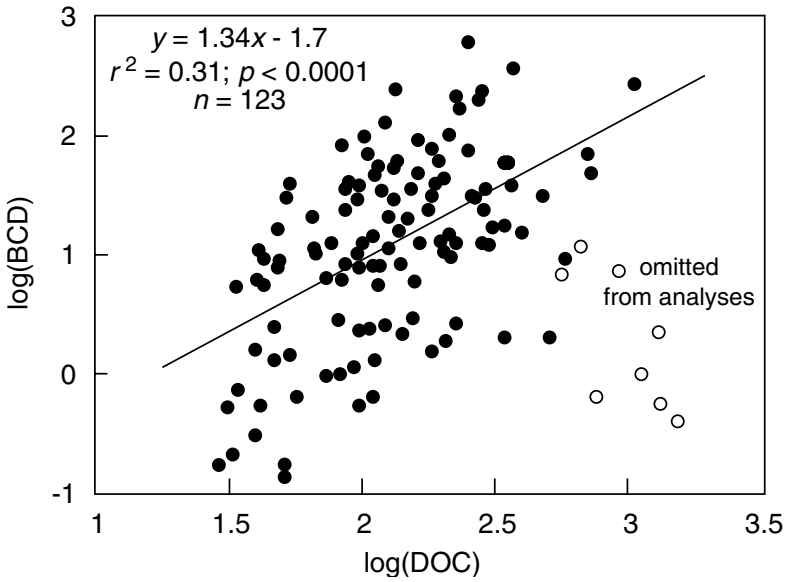

Figure 3 Relationship between ambient DOC concentrations $\left(\mathrm{mg} \mathrm{l}^{-1}\right)$ and bacterioplankton carbon demand (BCD; $\mu \mathrm{g}$ C per liter per hour).

winter $(0.57 \pm 0.05, n=9)$ and intermediate in spring $(0.37 \pm 0.03, n=38)$ and fall $(0.35 \pm 0.03, n=31)$. Mean BGE was significantly higher in winter and significantly lower in summer, and similar in spring and fall.

Relationship between carbon demand and growth efficiency. We observed a significant but relatively weak $\left(r^{2}=0.20\right)$ negative relationship between BGE and BCD when the entire data set was considered, although the strength of this relationship improved when the four subsystems were considered individually (Figure 4a). Stronger relationships were observed for data from LC $\left(r^{2}=0.50, n=25\right.$, $P<0.0001$; regression not shown) and $\mathrm{OB}$ $\left(r^{2}=0.38, n=27, P=0.0006\right.$; lower hatched line) when compared to the nutrient-enriched LMC ( $r^{2}=0.21, n=40, P=0.003$; upper hatched line) and $\mathrm{MC}\left(r^{2}=0.18, n=47, P=0.003\right.$; regression not shown). Consistent with the rank order observed among the subsystems, highest and lowest $y$ intercepts were observed for regression of data from LMC and $\mathrm{OB}$, respectively, and these were statistically different (analysis of covariance, $r^{2}=0.30, n=147$, $F=15.5, P<0.0001)$. Regressions of data from LC and MC (not shown) had $y$ intercepts that were intermediate relative to those of OB and LMC and statistically similar to that of the entire data set (solid line). Two estimates of BGE from the upper reaches of LMC measured in April 2000 and 2001 during annual maxima of agricultural nutrient inputs (Apple et al., 2004) were omitted from analyses.

A recent study of bacterioplankton carbon metabolism in this system suggests that temperature may influence BCD and BGE differently, with higher BCD and lower BGE at higher ambient water temperatures (Apple et al., 2006). In an effort to remove the potentially confounding effect of temperature on this relationship, we used residuals from the temperature dependence of BCD and BGE reported
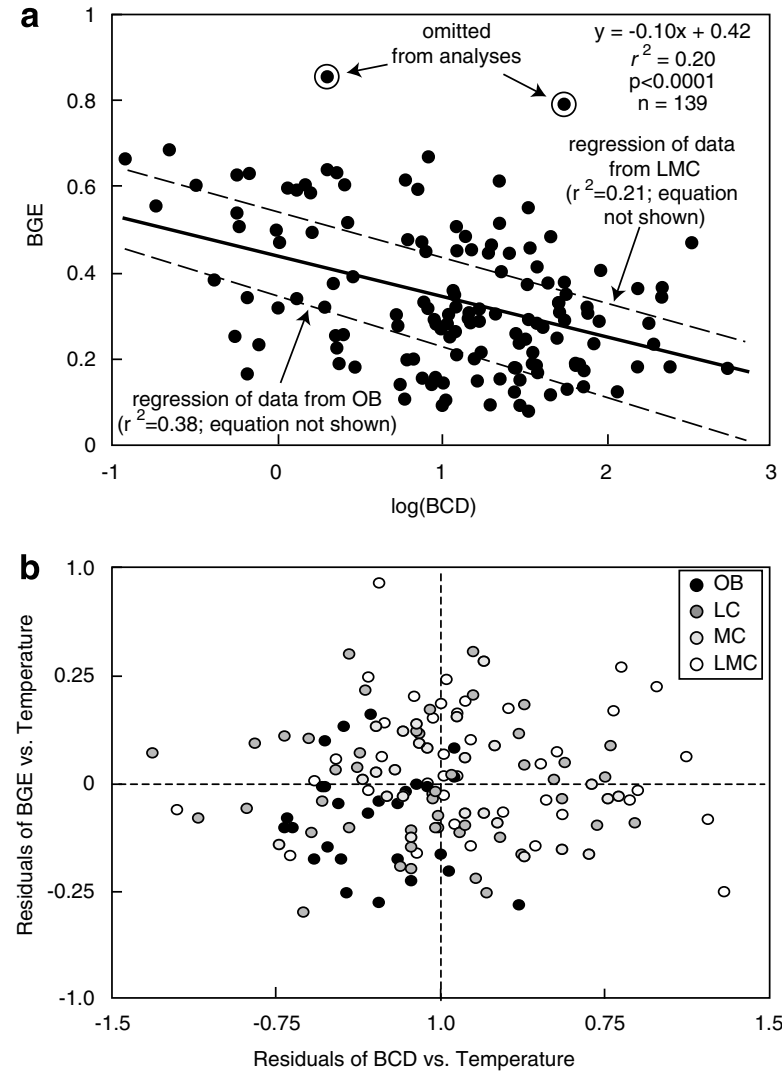

Figure 4 Relationship between (a) paired estimates of bacterial growth efficiency (BGE) and log-transformed values of bacterial carbon demand (BCD; $\mu \mathrm{g}$ C per liter per hour) and (b) residuals from regressions of BGE and BCD vs temperature.

by Apple et al. (2006) rather than absolute values (Figure 4b). Initial comparison of these data not only eliminated the negative correlation between BCD and BGE, but also suggested that there is no relationship whatsoever between these measures of carbon metabolism. However, patterns in the distribution of data with respect to subsystem were apparent, with data from OB located predominantly in the lower left quadrant, LMC in the upper right quadrant and MC and LC dispersed uniformly around the central axes. A more distinct pattern emerged when mean residuals from each subsystem were regressed, revealing a positive correlation of BGE and BCD (Figure 5a) that followed the rank order previously observed among subsystems and that was also correlated with DOC lability (Figure 5b).

\section{Ambient nutrient and DOC characteristics}

Dissolved organic carbon, absorbance of DOC at $350 \mathrm{~nm}$ and specific absorbance exhibited a similar rank order in magnitude among the four subsystems (Table 3). Highest DOC concentrations were observed in MC $\left(12.5 \mathrm{mgl}^{-1}\right)$, intermediate in LMC (9.6 $\mathrm{mgl}^{-1}$ ) and lowest in LC and OB (7.7 and $6.0 \mathrm{mgl}^{-1}$, respectively). Both absorbance and spe- 
a

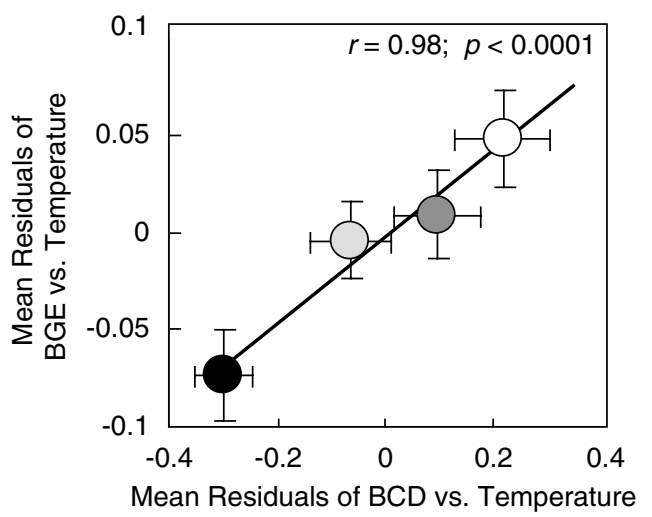

b

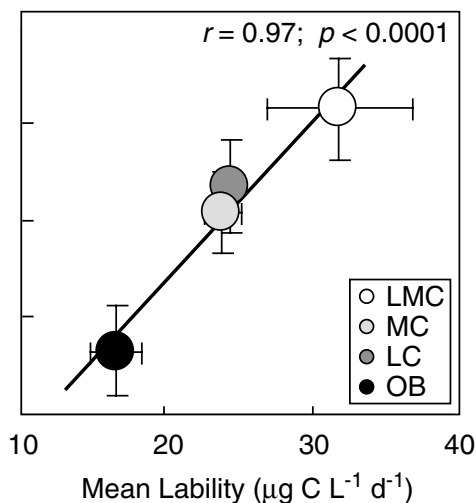

Figure 5 Correlations among subsystems for (a) mean temperature residuals for bacterial growth efficiency (BGE) vs those for bacterial carbon demand (BCD) and (b) mean temperature residuals for BGE vs mean lability.

a

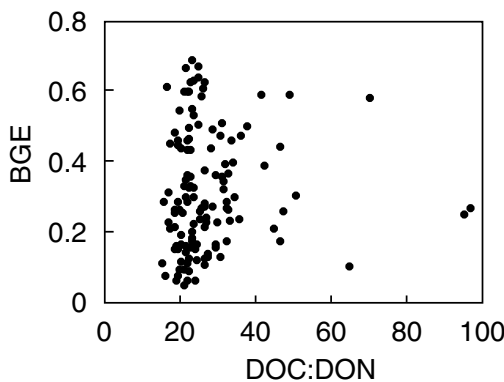

b

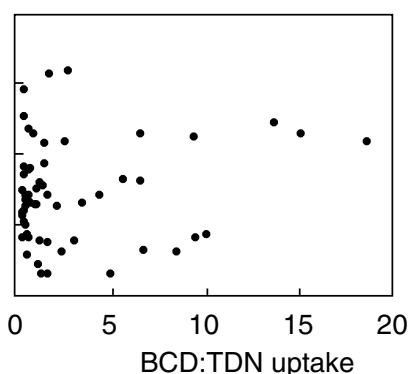

C

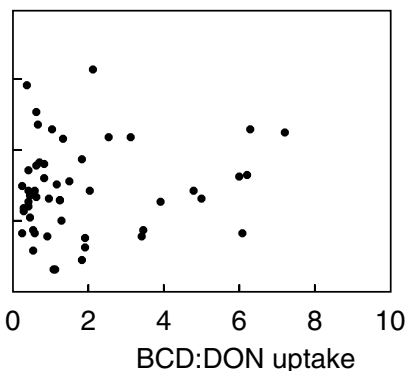

Figure 6 Relationship between bacterioplankton growth efficiency (BGE) and (a) molar ratios of ambient dissolved carbon and nitrogen (DOC:DON), (b) total carbon and nitrogen uptake by bacterioplankton (bacterioplankton carbon demand (BCD): total dissolved nitrogen (TDN) uptake) and (c) consumption of organic carbon and nitrogen by bacterioplankton (BCD:DON uptake). Carbon and nitrogen uptake ratios were derived from molar rates ( $\mu \mathrm{M}$ per hour).

cific absorbance were highest in MC $(0.23$ and 0.020 , respectively) and lowest in $\mathrm{OB}(0.07$ and 0.012 , respectively). Although absorbance of DOC was significantly different in LC and LMC, specific absorbance in LC was similar to that of both LMC and OB (Tukey-Kramer HSD, $n=119, \alpha=0.05$, $P<0.0001)$. Dissolved nutrient stoichiometry also differed among the subsystems. LC had the highest $\mathrm{C}: \mathrm{N}$ and $\mathrm{N}: \mathrm{P}$ ratios of all systems (Tukey-Kramer HSD, $n=183, \alpha=0.05, P<0.0001)$. C:N ratios were similar among the other subsystems and N:P ratios were similar and significantly lower in the two agriculturally developed creeks (Tukey-Kramer HSD, $n=183, \alpha=0.05, P<0.0001)$. Mean chlorophyll a concentrations among the subsystems ranged from 7.4 to $15.7 \mu \mathrm{gl}^{-1}$ and were highest in OB, lowest in LC and statistically similar among the three tidal creeks.

Nutrient uptake and carbon metabolism

Changes in dissolved nutrient concentrations during respiration incubations were highly variable and statistically significant relative to the error associated with the measurement of each analyte (Strickland and Parsons, 1972; Valderrama, 1981; Whitledge et al., 1981). Consumption of $\mathrm{NO}_{x}$ and dissolved organic nitrogen (DON) was observed in almost all incubations (90 out of 93), with mean uptake of $-0.07 \pm 0.01 \mu \mathrm{M} \mathrm{h}^{-1}$ and $-0.37 \pm 0.05 \mu \mathrm{M} \mathrm{h}^{-1}$ for $\mathrm{NO}_{x}$ and DON and maximum uptake -0.47 and $-1.5 \mu \mathrm{Mh}^{-1}$, respectively. In contrast, we observed both uptake and production of $\mathrm{NH}_{4}^{+}$, with a maximum uptake of $-0.26 \mu \mathrm{M} \mathrm{h}^{-1}$ and maximum production of $0.18 \mu \mathrm{M} \mathrm{h}^{-1}$. The overall mean of $-0.001 \pm 0.005 \mu \mathrm{Mh}^{-1}$ and the similarity in the number of incubations in which uptake of $\mathrm{NH}_{4}^{+}$vs production was observed (that is, 52 vs 40 ) suggest a general balance between uptake and production of $\mathrm{NH}_{4}^{+}$. This parity was observed in all subsystems but LC, where the majority of incubations (that is, 13 out of 18) exhibited net uptake of $\mathrm{NH}_{4}^{+}$. Changes in phosphorus concentrations during incubations were variable, ranging from -0.076 to $0.083 \mu \mathrm{Mh}^{-1}$ for TDP and -0.028 to $0.029 \mu \mathrm{Mh}^{-1}$ for $\mathrm{PO}_{4}^{3-}$. There was an overall balance between uptake and remineralization of all forms of dissolved phosphorus, although phosphate consumption was observed in the majority $(66 \%)$ of the incubations.

Ambient nutrient concentrations, nutrient uptake stoichiometry and BGE were combined to explore the effect of interactions between nutrients and DOC on growth efficiencies (Figure 6). There was no relationship between BGE and ambient nutrient 
stoichiometry (ambient DOC:DON; Figure 6a), uptake ratios of total carbon and nitrogen (BCD:TDN uptake; Figure 6b) and estimates of the $\mathrm{C}: \mathrm{N}$ ratio of organic matter substrates consumed by bacterioplankton (BCD:DON uptake; Figure 6c) when the composite data set was considered. We also observed no correlation between BGE and the proportion of $\mathrm{N}$ or $\mathrm{P}$ that was derived from organic vs inorganic sources (Figure 7).

The relative contribution of inorganic nitrogen and phosphorus to total nutrient uptake differed significantly among systems, as evidenced by dissolved inorganic nitrogen (DIN):TDN and $\mathrm{PO}_{4}$ :TDP uptake ratios (Table 4). In general, most of the $\mathrm{N}$ consumed by bacterioplankton in all subsystems appeared to be derived from DON, although the contribution of inorganic nitrogen uptake to total nitrogen uptake was significantly higher in OB than the three tidal creeks (Table 4). Phosphorus uptake exhibited a similar pattern among subsystems. Uptake in LC and LMC was generally balanced between organic and inorganic sources, although $\mathrm{P}$ uptake in MC was dominated by organic sources and that in $\mathrm{OB}$ was almost exclusively phosphate.

\section{Discussion}

Coherence of carbon demand, growth efficiency and DOC lability

A major objective of our study was to investigate the coherence of BGE and carbon demand and identify factors that influence their coupling. Initial analyses revealed a weak but significant negative relationship between BCD and BGE that was unexpected (Figure 4a), as we had anticipated a positive coupling of these two measures of carbon metabolism driven by higher growth efficiencies and elevated rates of carbon demand typically associated with more productive systems and/or metabolically active bacterioplankton communities (Bjørnsen et al., 1989; del Giorgio and Cole, 1998; Pace and
Cole, 2000). However, the positive rank order among $y$ intercepts-with highest BGE per unit BCD in agriculturally impacted LMC and lowest in OBsuggests an underlying positive relation of BCD and BGE that may reflect differences in resource supply among the subsystems of OB. Indeed, when we removed the effect of temperature on bacterioplankton carbon metabolism documented previously in this system by regressing mean residuals of the temperature dependence of BCD and BGE (Apple et al., 2006), we observed a positive relation of BCD and BGE and a rank order among subsystems (Figure 5a) that was also observed 2-year means (Table 2) and $y$ intercepts of the BCD vs BGE relationship (Figure 4a).

The positive relationship between BCD and BGE observed in these regressions could result from either strong physiological link between carbon demand and growth efficiency-and thus common regulation of the two by a single environmental factor-or simply that these two aspects of carbon metabolism covary with different ecosystem properties that may all be linked to system productivity. In the sections below we discuss the potential role of

Table 4 Systematic differences in the relative contribution of inorganic nutrient uptake to total dissolved nutrient uptake $($ mean \pm s.e. $(n))$

\begin{tabular}{lrrrrrr}
\hline & \multicolumn{2}{c}{$\begin{array}{c}\text { DIN:TDN } \\
\text { uptake }\end{array}$} & \multicolumn{3}{c}{$\begin{array}{c}\text { PO }_{4}: T D P \\
\text { uptake }\end{array}$} \\
\hline Open Bay & $0.43 \pm 0.06$ & $(10)$ & A & $0.80 \pm 0.13$ & $(6)$ & A \\
Little Creek & $0.27 \pm 0.07$ & $(8)$ & A B & $0.45 \pm 0.14$ & $(5)$ & A B \\
Little Monie & $0.24 \pm 0.07$ & $(9)$ & A B & $0.43 \pm 0.09$ & $(13)$ & B \\
$\begin{array}{l}\text { Creek } \\
\text { Monie Creek }\end{array}$ & $0.17 \pm 0.06$ & $(11)$ & B & $0.21 \pm 0.09$ & $(11)$ & B
\end{tabular}

Abbreviations: DIN, dissolved inorganic nitrogen; TDN, total dissolved nitrogen; TDP, total dissolved phosphorus.

Means sharing the same letter are statistically similar (Tukey-Kramer HSD, $\alpha=0.1$; DIN:TDN: $n=38, \quad$ F-ratio $=3.1, P=0.04 ; \mathrm{PO}_{4}$ :TDP: $n=35$, F-ratio $=4.8, P=0.008$ ).
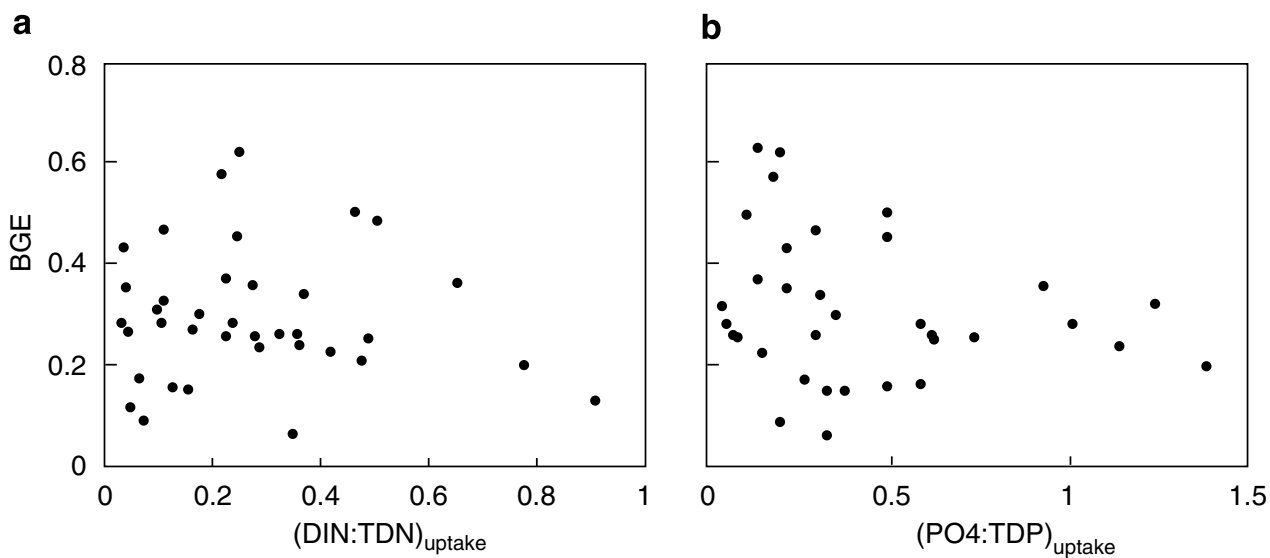

Figure 7 Relationship between bacterial growth efficiency (BGE) and the relative contributions of (a) dissolved inorganic nitrogen (DIN) to total dissolved nitrogen (TDN) uptake $(n=35)$ and $(\mathbf{b})$ dissolved phosphate $\left(\mathrm{PO}_{4}\right)$ to total dissolved phosphorus $(\mathrm{TDP})$ uptake $(n=37)$. Uptake ratios were derived from molar rates $(\mu \mathrm{M}$ per hour). 
organic matter quality in shaping bacterial carbon metabolism in this estuarine system, including absorbance, specific absorbance, lability, uptake stoichiometry, and both concentration and stoichiometry of the dissolved nutrient pool.

\section{Comparisons among creeks reveal influence of DOC} quality on $B C D$ and $B G E$

Consistent rank order in the magnitude of both BCD and BGE among subsystems would suggest that the factor or factors responsible for driving BCD and BGE must also vary among the four subsystems in a systematic manner that influences patterns in carbon metabolism. Increases in bacterioplankton carbon metabolism have been frequently associated with increases in ambient nutrient concentrations (Carlson and Ducklow, 1996) and there is little doubt that inputs of dissolved nutrients contribute to the overall productivity of $\mathrm{OB}$ and other similar estuarine ecosystems. Higher BCD, DOC and dissolved nutrient concentrations in enriched LMC relative to un-enriched LC (Table 3; Apple et al., 2004) would suggest that bacterial carbon metabolism could be driven by either DOC supply, nutrient concentrations or the combined effect of both. However, relatively low BCD in nutrient-enriched MC indicates that nutrient concentrations alone are not responsible for driving increases in BCD. Indeed, we observed a significant positive relationship between ambient DOC concentrations and BCD (Figure 3) suggesting that the rate of supply of organic matter also plays a role in regulating carbon metabolism, even in this extremely carbon-rich system. However, this relationship shows a large range in bacterial carbon metabolism for any given DOC concentration, suggesting further that differences in the degradability and perhaps quality of DOC-rather than rate of supply or ambient DOC concentrations alone-play a major role in shaping bacterial carbon metabolism.

In this regard, long-term DOC lability was positively correlated with both mean residual BGE (Figure 5b) and BCD $(r=0.95, P<0.0001$; comparison not shown), suggesting a link between both expressions of carbon metabolism and qualitative aspects of the DOC pool. However, the positive relationship between short-term metabolic rates and long-term DOC consumption should not be interpreted as direct and causal, as these approaches target quite different components of the DOC pool. Short-term metabolic rates are fueled primarily by a highly labile and ephemeral component of the DOC pool that has a relatively short (that is, minutes to hours) turnover time (Connolly and Coffin, 1995; Søndergaard and Middelboe, 1995). This DOC does not tend to accumulate in the bulk DOC pool and thus is not reflected in ambient DOC concentrations. In contrast, long-term bioassays follow the consumption of a semi-labile DOC pool that remains after the highly labile pool has been consumed
(Connolly and Coffin, 1995; del Giorgio and Davis, 2003). In this regard, characteristics of the DOC pool exhibiting intermediate lability (that is, days to weeks) should not in principle help explain in situ rates of short-term bacterial carbon metabolism. Indeed, previous studies in the Hudson River have shown that these two DOC pools do not covary (del Giorgio and Pace, in press). Moreover, higher measures of DOC lability in long-term incubations are not necessarily indicative of higher quality carbon, as there are compounds that may be highly labile but energy poor, while others may be less labile but more energetically or nutritionally advantageous for bacterial growth. For example, carbonrich terrestrial detritus and algal exudates differ substantially in their degradability, yet subsidy of bacterioplankton growth by either would most likely yield relatively low BGE. In contrast, nitrogen-rich substrates such as dissolved free amino acids would yield higher values for both lability and BGE. Despite these considerations, the fact that shortterm carbon consumption and BGE are both related to long-term DOC lability would suggest that in OB, there is a connection between biologically relevant properties of the highly labile and semi-labile pools and that the systematic differences in long-term DOC lability that we detected among subsystems do reflect basic differences in the average energetic and structural characteristics of the available carbonincluding that which turns over rapidly. In turn, these systematic qualitative differences can be traced to differences in the major sources of organic matter in each of the subsystems that comprise the OB system.

The fact that variations in the nature of the DOC pool in OB play a major role in regulating bacterial carbon metabolism is further evidenced by the contrasting patterns of in situ metabolism in the different subsystems. Evidence that the bioreactivity and quality of organic matter in MC are lower is provided by consistently lower measures of carbon metabolism (that is, BP, BR, BGE and BCD) in MC relative to that of LMC despite higher DOC concentrations and similar degree of nutrient enrichment. Indeed, MC exhibited the highest CDOM and lowest percentage of labile DOC, indicating the presence of high-molecular weight terrestrial organic matter (McKnight et al., 2001), which may be more resistant to microbial degradation in estuaries (Søndergaard et al., 2003; Boyd and Osburn, 2004). Although ambient DOC concentrations in MC were twice that of un-enriched LC, BCD and lability between the two creeks were strikingly similar, further supporting the role of lower quality organic matter in regulating the magnitude of carbon metabolism. Further, data collected in MC during April of 2000 and 2001 (Figure 3, open circles) when loading of terrestrial DOC to this system was highest (Apple et al., 2004) provide an example of what happens in the presence of elevated inputs of terrestrially derived organic matter. The general deviation of 
data from MC with respect to patterns in BCD and BGE relationships suggests DOC of a much lower bioreactivity and lower overall nutritional quality. In contrast, large anthropogenic nutrient inputs to LMC fuel a highly productive marsh macrophyte community that yields plant biomass and ultimately detrital organic matter with relatively high nitrogen and phosphorus content (Jones et al., 1997), which is of higher quality and more readily degraded by bacterioplankton (Bano et al., 1997; Reitner et al., 1999). Elevated rates of BCD in this subsystem are probably a response to an increase in both carbon supply and the presence of organic matter that is both more labile and of higher quality.

Comparisons among creeks provided further evidence that qualitative aspect of organic matter was also important in determining patterns of BGE among subsystems. Despite significant differences in ambient nutrient and dissolved carbon concentrations between LMC and LC (Table 3; Apple et al., 2004), BGE was almost identical (0.34 and 0.35, respectively; Student's $t$-test; $t_{\text {calc }}=2.7$, d.f. $=68$, $P<0.005)$ and higher than that of the other subsystems (Table 2). Both LMC and LC are characterized by extensive Spartina alterniflora marshes and lower inputs of terrestrial organic matter (Jones et al., 1997; Apple et al., 2004), suggesting that organic substrates available for utilization by bacterioplankton in these two creeks are similar and possibly of higher energetic or nutritional quality, being derived predominantly from marsh production and thus capable of supporting higher rates of bacterioplankton production and growth efficiencies than in systems dominated by terrestrially derived organic matter (Bano et al., 1997; Reitner et al., 1999). The fact that average BGE was lower in terrestrially influenced MC (0.29) where the highest nutrient and DOC concentrations were recorded (Apple et al., 2004) further supports the importance of organic matter quality rather than dissolved nutrients in dictating the magnitude of BGE. These patterns in bacterial carbon consumption and processing among the tidal creeks indicate that in turbid, eutrophic, carbon-rich marshes and estuaries such as OB, organic matter quality may have a more important and direct effect on the regulation of carbon metabolism. These observations are consistent with previous studies suggesting that the quality and composition of organic matter may be more important than nutrients alone in regulating growth efficiency (Kroer, 1993; Middelboe and Søndergaard, 1993; Pradeep Ram et al., 2003), a conclusion which may be particularly applicable to eutrophic, carbon-rich estuaries such as OB.

\section{Nutrient content of organic matter, nutrient uptake} dynamics and bacterial growth efficiency

Thus far our discussion has addressed degradability (that is, lability) and optical properties of DOC as proxies for organic matter quality (Søndergaard et al., 2003; Boyd and Osburn, 2004). Another key aspect influencing the consumption, processing and fate of organic matter is nutrient content and elemental stoichiometry, as well as the availability of dissolved inorganic nutrients (Kirchman, 2000). Most studies investigating the influence of dissolved organic matter (DOM) stoichiometry on bacterial carbon metabolism have focused on relative concentrations of carbon and nitrogen in the ambient waters (for example, DOC:DON or total C:N), relating this to the stoichiometric demands of bacterioplankton growth (Goldman et al., 1987; Vallino et al., 1996; Sun et al., 1997; Touratier et al., 1999; Kirchman, 2000). However, our analyses provided no evidence that ambient dissolved nutrient stoichiometry influences BGE (Figure 6a).

This lack of relationship between BGE and ambient DOC:DON or DOC:DOP ratios is not surprising, as these ratios represent DOC and nutrients to which bacterioplankton are potentially exposed rather than that which they actually consume. Indeed, it is the molar ratio of carbon consumption and nutrient uptake (that is, BCD: $\triangle \mathrm{TDN}$ and BCD: $\triangle \mathrm{DON}$ ) that provides a more relevant proxy for investigating the relationship between organic matter quality and BGE, as it offers a more accurate approximation of the C:N ratio of organic matter that is actually consumed by bacterioplankton. However, we found no link between BGE and the carbon and nutrient uptake stoichiometry, neither for total nitrogen (BCD: $\triangle \mathrm{TDN}$ ) nor for organic nitrogen (BCD: $\triangle \mathrm{DON}$ ) uptake (Figures $6 \mathrm{~b}$ and c). This leads to the conclusion that DOM nutrient stoichiometry is not the main factor regulating BGE in these tidal creeks, marshes and surrounding estuarine waters.

Bacteria can meet their stoichiometric requirements by the uptake of both organic and inorganic forms of nitrogen and phosphorus. For example, DOM that is depleted in $\mathrm{N}$ or $\mathrm{P}$ relative to the demands of bacterioplankton growth may require the expenditure of additional energy for uptake and assimilation of inorganic nutrients, ultimately resulting in lower growth yield and BGE (Kirchman, 2000). We explored the extent to which uptake of organic nutrients may have been supplemented by active uptake of dissolved inorganic nutrients. Using direct measurements of the uptake of dissolved inorganic nutrients (that is, DIN and $\mathrm{PO}_{4}^{3-}$ ) relative to total uptake (that is, TDN and TDP), we estimated the proportion of $\mathrm{N}$ and $\mathrm{P}$ derived from inorganic sources and explored the relationship between these values and BGE (Figure 7). We hypothesized that lower growth efficiencies would be associated with higher DIN:TDN and $\mathrm{PO}_{4}$ :TDP uptake ratios, as these represent circumstances where most nutrient acquisition is derived from active uptake of the inorganic fraction. The patterns in Figure 7 support the first part of this hypothesis, with lower BGE generally encountered when a greater proportion of nutrient uptake was from the 
inorganic fraction (that is, higher uptake ratios). However, conditions under which nutrients were derived predominantly from DOM (that is, lower uptake ratios) did not necessarily result in consistently higher BGE, and although relatively high growth efficiencies were observed at low nitrogen and phosphorus uptake ratios, there was considerable variability $(<0.1$ to $>0.6)$.

Lower values of BGE when nutrients are derived predominantly from organic sources suggest utilization of DOM of a more refractory nature that, despite adequate nutrient content, involves a higher metabolic cost for degradation, consumption and incorporation into biomass (Linton and Stevenson, 1978). Comparison of $\mathrm{N}$ and $\mathrm{P}$ uptake ratios among subsystems (Table 4) provides evidence of the combined effects of these different aspects of DOM quality (that is, energetic quality vs nutrient content) on BGE. Despite elevated nutrient concentrations and evidence of nutrient-rich DOM in MC (that is, low inorganic to total nutrient uptake ratios), BGE in this system was characteristically low. As discussed previously, this would point to the consumption of more recalcitrant substrate of lower energetic or nutritional value, the effect of which is significant enough to override the potential positive effect of elevated $\mathrm{N}$ and $\mathrm{P}$ on BGE. Further evidence of the interaction of substrate quality and nutrient content was observed in a comparison of LMC and LC, where bacterioplankton appeared to derive a greater proportion of $\mathrm{N}$ and $\mathrm{P}$ from inorganic sources than those in MC. Yet BGE in these systems is consistently higher than that in MC, and we hypothesize that this is a direct effect of differences in DOC composition in these two tidal creeks. Although they differ markedly with respect to ambient nutrient concentrations, nutrient uptake ratios in LMC and LC are almost identical, probably reflecting a similarity in DOM source (that is, Spartina) that also entails similarity in chemical, nutrient and energy characteristics.

It is important to note that the lack of relationship between nutrient uptake and BGE observed in our study may be attributed in part to discrepancies between measured and actual nutrient uptake. For example, based on theoretical stoichiometric demands of bacterioplankton growth (Goldman et al., 1987; Fukuda et al., 1998), we often measured rates of nitrogen uptake in excess of the nitrogen demand expected given observed changes in bacterial cell abundance and estimates of leucine production, resulting in C:N uptake ratios that were below those of bacterial biomass or known species of organic molecules (Figures 6b and c) and that could not be accounted for by $\mathrm{NH}_{4}^{+}$production. Assimilation of nitrogen in excess of bacterial growth demands is not uncommon, yet the underlying mechanisms are not well understood (Kirchman, 2000). Others have suggested unmeasured excretion of different forms of DON may explain the discrepancy between nitrogen uptake and nitrogen demand (Berman et al., 1999; Jørgensen et al., 1999; Kirchman et al., 2001). Differences in the length of incubation used to derive bacterial carbon metabolism $(\sim 6 \mathrm{~h})$ and nutrient consumption $(<18 \mathrm{~h})$ may lead to a temporal uncoupling between consumption and respiration of organic matter and assimilation of DON and other nutrient forms for growth, resulting in unrealistically low C:N uptake ratios. This might also occur if the rate of dissolved nutrient uptake during the later part of $18 \mathrm{~h}$ incubations was higher than during the initial $6 \mathrm{~h}$ when BCD was measured. Regardless of the mechanism driving the low C:N ratios observed in our study, it is clear that nutrient uptake by bacterioplankton, its relation to BCD and role in regulating BGE is poorly understood and needs to be explored in greater detail.

It has been reported that differences in leucinebased estimates of BP may be driven in part by variation in the in the efficiency with which leucine is converted into bacterial biomass and that the use of a constant leucine-to-CCF may inaccurately represent in situ rates of BP and BGE (Kirchman, 1993; Buesing and Marxsen, 2005; Alonso-Sáez et al., 2007). Although the influence of variability in CCF may be most pronounced in oligotrophic waters (Alonso-Sáez et al., 2007), this phenomenon may be applicable to any range of systems differing in productivity or degree of resource enrichment. We recognize that patterns in BGE among the subsystems of $\mathrm{OB}$ may reflect systematic variability in CCFs and therefore investigated the relationship between leucine incorporation and POC production. We observed a strong, highly significant positive relationship between estimates of $\mathrm{BP}$ derived from changes in POC and those derived from applying a constant CCF to rates of leucine incorporation (Figure 8), indicating that the use of a constant CCF (that is, $3.1 \mathrm{~kg} \mathrm{C}$ mol per leucine; Kirchman, 1993) may be appropriate for estimating $\mathrm{BP}$ in $\mathrm{OB}$ and other marsh-dominated estuaries. Given the apparent accuracy of our estimates of BP and the

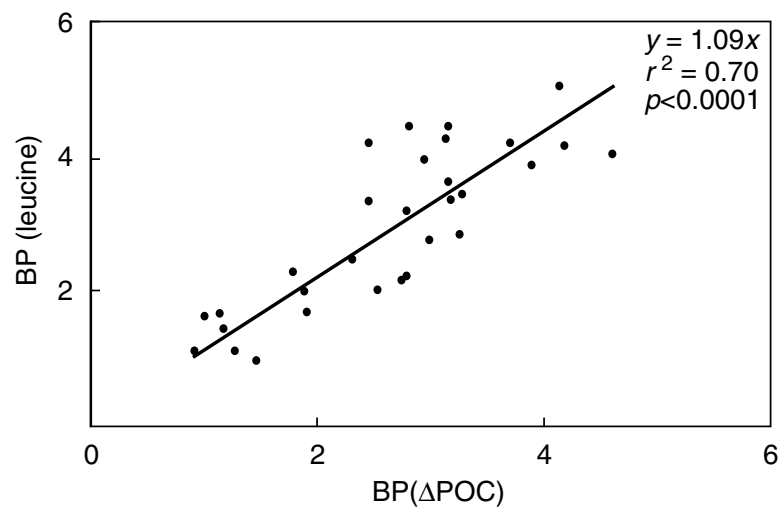

Figure 8 Comparison of estimates of bacterial production (BP; $\mu \mathrm{g}$ $\mathrm{C}$ per liter per hour) derived from changes in particulate organic carbon $(\triangle \mathrm{POC})$ vs those derived from rates of leucine incorporation and the application of a constant leucine-to-CCF of $3.1 \mathrm{~kg} \mathrm{C}$ mol per leucine. 
independence of BR and BCD from variation in CCF (Alonso-Sáez et al., 2007), we conclude that if systematic differences in CCF exist among the subsystems of $\mathrm{OB}$, their influence is minimal and will not likely change the patterns in carbon metabolism reported in our study.

\section{Concluding remarks}

The environmental factors underlying patterns in bacterial carbon metabolism in coastal, estuarine and tidal marsh systems (for example, Revilla et al., 2000; Smith and Kemp, 2003; Apple et al., 2004) have been traditionally difficult to identify and isolate, in part because key factors such as nutrient availability, organic carbon quality and supply, and salinity tend to covary (Fisher et al., 1988). The OB system, with its combination of open estuarine waters, tidal marshes and creeks with various degrees of freshwater influence provides a useful venue to investigate controls of bacterial metabolism because it offers steep, independent gradients in several key environmental factors, including the amount and nature of organic matter and nutrients. Comparisons among the OB subsystems allowed us to isolate the key environmental factors influencing the regulation and coupling of BCD and BGE that might otherwise not be apparent in other studies.

Bacterial carbon demand and growth efficiency varied greatly among these subsystems and along environmental gradients, yet we were able to identify a positive relationship between these two key aspects of bacterial carbon metabolism. The range and overall mean BGE recorded in our study were remarkably similar to those reported by del Giorgio and Cole (1998) in their survey of over 40 studies representing lakes, rivers, estuaries and the open ocean. Thus, although mean growth efficiencies are generally higher in temperate estuaries, the variability of BGE within this system of tidal creeks appears to be comparable to that of all aquatic systems. Our observations emphasize the importance of organic matter quality in the regulation of both bacterial carbon consumption and of the fate of the carbon consumed (for example, BGE). Although we were not able to determine the specific qualitative aspect of DOM that is involved in the regulation of bacterial carbon metabolism, we did identify long-term DOC lability as a qualitative factor that is positively related to both BCD and BGE. We further established that the nutrient content of DOM may not be as important in regulating BGE as is frequently assumed, at least in the range of moderately to highly enriched systems that we studied. Although models of bacterioplankton metabolism frequently rely on organic matter stoichiometry to explain variations in BGE (Goldman et al., 1987; Touratier et al., 1999), we found little evidence supporting this as a valid assumption for our systems. This in turn suggests that other qualitative aspects of DOC, such as bioreactivity and energetic content, must play a major role in shaping bacterial carbon metabolism. Further, we have shown that the stoichiometry of carbon vs total nutrient uptake (that is, the availability of both organic and inorganic $\mathrm{N}$ and $\mathrm{P}$ relative to that of carbon) does not seem to play a major role in regulating BGE in these systems either. Numerous studies have used dissolved C:N ratios as a measure of the quality of DOM available to bacterioplankton (Vallino et al., 1996; Sun et al., 1997; Touratier et al., 1999; Kirchman, 2000; Rodrigues and Williams, 2001), yet our study indicates that not only is this a poor predictor of what bacterioplankton actually consume, but that exclusive use of this as a measure of organic matter quality fails to account for other bioenergetically relevant characteristics of quality that also strongly influence BGE.

We conclude that in nutrient-rich systems such as the tidal marshes and creeks of OB and estuaries in general, organic matter quality plays a key role in modulating the effect of DOM nutrient stoichiometry on bacterioplankton carbon metabolism. In this regard, simple stoichiometric models may fail to fully describe the effect of DOM quality on bacterioplankton metabolism, and more complex indices of quality incorporating nutrient uptake and substrate degradability are necessary to more effectively predict the effect of organic matter quality on growth efficiency and carbon consumption.

\section{Acknowledgements}

This research was funded in part by a Graduate Research Fellowship awarded by the National Estuarine Research Reserve System (NERRS) and by a grant from the Cooperative Institute for Coastal and Estuarine Environmental Technology (CICEET). We thank S Canut for support and inspiration and W Kemp, D Stoecker, D Kirchman, T Fisher and R Newell for their practical and intellectual contributions to this project.

\section{References}

Alonso-Sáez L, Gasol JM, Arístegui J, Vilas JC, Vaqué D, Duarte CM et al. (2007). Large-scale variability in surface bacterial carbon demand and growth efficiency in the subtropical northeast Atlantic Ocean. Limnol Oceanogr 52: 533-546.

Apple JK, del Giorgio PA, Kemp WM. (2006). Temperature regulation of bacterial production, respiration, and growth efficiency in estuarine systems. Aquat Microb Ecol 43: 243-254.

Apple JK, del Giorgio PA, Newell RIE. (2004). The effect of system-level nutrient enrichment on bacterioplankton production in a tidally-influenced estuary. J Coast Res 45: 110-133.

Bano N, Nisa M, Khan N, Saleem M, Harrison PJ, Ahmed S et al. (1997). Significance of bacteria in the flux of organic matter in the tidal creeks of the mangrove 
ecosystem of the Indus River delta, Pakistan. Mar Ecol Prog Ser 157: 1-12.

Berman T, Bechemin C, Maestrini SY. (1999). Release of ammonium and urea from dissolved organic nitrogen in aquatic ecosystems. Aquat Microb Ecol 16: 295-302.

Bjørnsen PK, Riemann B, Pock-Steen J, Nielsen TG, Horsted SJ. (1989). Regulation of bacterioplankton production and cell volume in a eutrophic estuary. Appl Environ Microbiol 55: 1512-1518.

Boyd TJ, Osburn CL. (2004). Changes in CDOM fluorescence from allochthonous and autochthonous sources during tidal mixing and bacterial degradation in two coastal estuaries. Mar Chem 89: 189-210.

Buesing N, Marxsen J. (2005). Theoretical and empirical conversion factors for determining bacterial production in freshwater sediments via leucine incorporation. Limnol Oceanogr Methods 3: 101-107.

Carlson CA, Ducklow HW. (1996). Growth of bacterioplankton and consumption of dissolved organic carbon in the Sargasso Sea. Aquat Microb Ecol 10: 69-85.

Cole JJ, Findlay S, Pace ML. (1988). Bacterial production in fresh and saltwater ecosystems: a cross system overview. Mar Ecol Prog Ser 43: 1-10.

Connolly JP, Coffin RB. (1995). Model of carbon cycling in planktonic food webs. J Env Eng 121: 682-690.

Coveney MF, Wetzel RG. (1992). Effects of nutrients on specific growth rate of bacterioplankton in oligotrophic lake water cultures. Appl Environ Microbiol 58: $150-156$.

del Giorgio PA, Bouvier TC. (2002). Linking the physiologic and phylogenetic successions in free-living bacterial communities along an estuarine salinity gradient. Limnol Oceanogr 47: 471-486.

del Giorgio PA, Cole JJ. (1998). Bacterial growth efficiency in natural aquatic systems. Annu Rev Ecol Sys 29: 503-541.

del Giorgio PA, Davis J. (2003). Patterns in dissolved organic matter lability and consumption across aquatic ecosystems. In: Findlay S. (ed). Aquatic Ecosystems: Interactivity of Dissolved Organic Matter. Elsevier Science: San Diego, pp 399-424.

del Giorgio PA, Pace ML. (in press). Relative independence of dissolved organic carbon transport and processing in a large temperate river: the Hudson River as both pipe and reactor. Limnol Oceanogr.

Ducklow HW, Purdie DA, Williams PJLB, Davies JM. (1986). Bacterioplankton: a sink for carbon in a coastal marine plankton community. Science 232: 863-867.

Felip M, Pace ML, Cole JJ. (1996). Regulation of planktonic bacterial growth rates: the effects of temperature and resources. Microb Ecol 31: 15-28.

Fisher TR, Harding LW, Stanley DW, Ward LG. (1988). Phytoplankton, nutrients, and turbidity in the Chesapeake, Delaware, and Hudson estuaries. Estuar Coast Shelf Sci 27: 61-93.

Fukuda R, Ogawa H, Nagata T, Koike I. (1998). Direct determination of carbon and nitrogen contents of natural bacterial assemblages in marine environments. Appl Environ Microbiol 64: 3352-3358.

Goldman JC, Caron DA, Dennet MR. (1987). Regulation of gross growth efficiency and ammonium regeneration in bacteria by $\mathrm{C}: \mathrm{N}$ ratio. Limnol Oceanogr 32: 1239-1252.

Hoch MP, Kirchman DL. (1995). Ammonia uptake by heterotrophic bacteria in the Delaware Estuary and adjacent coastal waters. Limnol Oceanogr 40: 886-897.
Hu C, Muller-Karger FE, Zepp RG. (2002). Absorbance, absorption coefficient, and apparent quantum yield: a comment on common ambiguity in the use of these optical concepts. Limnol Oceanogr 47: 1261-1267.

Jørgensen NOG, Kroer N, Coffin RB, Hoch MP. (1999). Relations between bacterial nitrogen metabolism and growth efficiency in an estuarine and an open-water ecosystem. Aquat Microb Ecol 18: 247-261.

Kana TM, Darkangelo C, Hunt MD, Oldham JB, Bennet GE, Cornwell JC. (1994). Membrane inlet mass-spectrometer for rapid high-precision determination of $\mathrm{N}_{2}, \mathrm{O}_{2}$, and $\mathrm{Ar}$ in environmental water samples. Anal Chem 66: $4166-4170$.

Kirchman DL. (1993). Leucine incorporation as a measure of biomass production by heterotrophic bacteria (Chapter 58). In: Kemp PF, Sherr BF, Sherr EB and Cole JJ (ed). Handbook of Methods in Aquatic Microbial Ecology. CRC Press: Boca Raton, pp 776.

Kirchman DL. (2000). Uptake and regeneration of inorganic nutrients by marine heterotrophic bacteria. In: Kirchman DL (ed). Microbial Ecology of the Oceans. Wiley: New York, NY, pp 261-288.

Kirchman DL, Yu L, Fuchs BM, Amann RL. (2001). Structure of bacterial communities in aquatic systems as revealed by filter PCR. Aquat Microb Ecol 26: $13-22$.

Kroer N. (1993). Bacterial-growth efficiency on natural dissolved organic-matter. Limnol Oceanogr 38: 1282-1290.

Linton J, Stevenson R. (1978). A preliminary study on growth yields in relation to the carbon and energy content of various organic growth substrates. FEMS Microbiol Lett 3: 95-98.

McKnight DM, Boyer EW, Westerhoff PK, Doran PT, Kulbe T, Anderson DT. (2001). Spectrofluorometric characterization of dissolved organic matter for indication of precursor organic material and aromaticity. Limnol Oceanogr 46: 38-48.

Middelboe M, Søndergaard M. (1993). Bacterioplankton growth yield: seasonal variations and coupling to substrate lability and beta-glucosidase activity. Appl Environ Microbiol 59: 3916-3921.

Moran MA, Sheldon JE, Zepp RG. (2000). Carbon loss and optical property changes during long-term photochemical and biological degradation of estuarine dissolved organic matter. Limnol Oceanogr 45: 1254-1264.

Pace ML, Cole JJ. (2000). Effects of whole-lake manipulations of nutrient loading and food web structure on planktonic respiration. Can J Fish Aquat Sci 57: 487-496.

Paerl HW, Dyble J, Moisander PH, Noble RT, Piehler MF, Pinckney JL et al. (2003). Microbial indicators of aquatic ecosystem change: current applications to eutrophication studies. FEMS Microbiol Ecol 46: 233-246.

Pradeep Ram AS, Nair S, Chandramohan D. (2003). Bacterial growth efficiency in the tropical estuarine and coastal waters of Goa, southwest coast of India Microb Ecol 45: 88-96.

Reitner B, Herzig A, Herndl G. (1999). Dynamics in bacterioplankton production in a shallow, temperate lake (Lake Neusiedl, Austria): evidence for dependence on macrophyte production rather than on phytoplankton. Aquat Microb Ecol 19: 245-254.

Revilla M, Iriarta A, Madariaga I, Orive E. (2000). Bacterial and phytoplankton dynamics along a trophic gradient in a shallow temperate estuary. Estuar Coast Shelf Sci 50: $297-313$. 
Rodrigues RM, Williams PJlB. (2001). Heterotrophic bacterial utilization of nitrogenous and nonnitrogenous substrates, determined from ammonia and oxygen fluxes. Limnol Oceanogr 46: 1675-1683.

Sharp J, Benner R, Bennet L, Carlson C, Fitzwater S, Peltzer E et al. (1995). Analyses of dissolved organic carbon in sea water: the JGOFS EqPac methods comparison. Mar Chem 48: 91-108.

Sherr BF, Sherr EB, Hopkinson CS. (1988). Trophic interactions within pelagic microbial communities: indications of feedback regulation of carbon flow. Hydrobiologia 159: 19-26.

Smith DC, Azam F. (1992). A simple, economical method for measuring bacterial protein synthesis rates in seawater using super(3)H-leucine. Mar Microb Food Webs 6: 107-114.

Smith EM, Kemp WM. (2003). Planktonic and bacterial respiration along an estuarine gradient: responses to carbon and nutrient enrichment. Aquat Microb Ecol 30: 251-261.

Søndergaard M, Middelboe M. (1995). A cross system analysis of labile dissolved organic carbon. Mar Ecol Prog Ser 118: 283-294.
Søndergaard M, Stedmon CA, Borch NH. (2003). Fate of terrigenous dissolved organic matter (DOM) in estuaries: aggregation and bioavailability. Ophelia 57: 161-176.

Strickland JD, Parsons TR. (1972). A Practical Handbook of Seawater Analysis. Fisheries Research Board of Canada: Ottawa, 167. pp 1-310.

Sun L, Perdue E, Meyer J, Weis J. (1997). Use of elemental composition to predict bioavailability of dissolved organic matter in a Georgia river. Limnol Oceanogr 42: 714-721.

Touratier F, Legendre L, Vézina A. (1999). Model of bacterial growth influenced by substrate C:N ratio and concentration. Aquat Microb Ecol 19: 105-118.

Valderrama JC. (1981). The simultaneous analysis of total nitrogen and total phosphorus in natural waters. Mar Chem 10: 109-122.

Vallino JJ, Hopkinson CS, Hobbie JE. (1996). Modeling bacterial utilization of dissolved organic matter: optimization replaces Monod growth kinetics. Limnol Oceanogr 41: 1591-1609.

Whitledge TE, Malloy SC, Patton CJ, Wirick CD. (1981). Automated nutrient analysis in seawater. Tech. Rep. BNL-51398, Brookhaven Natl. Lab., Upton, NY. 